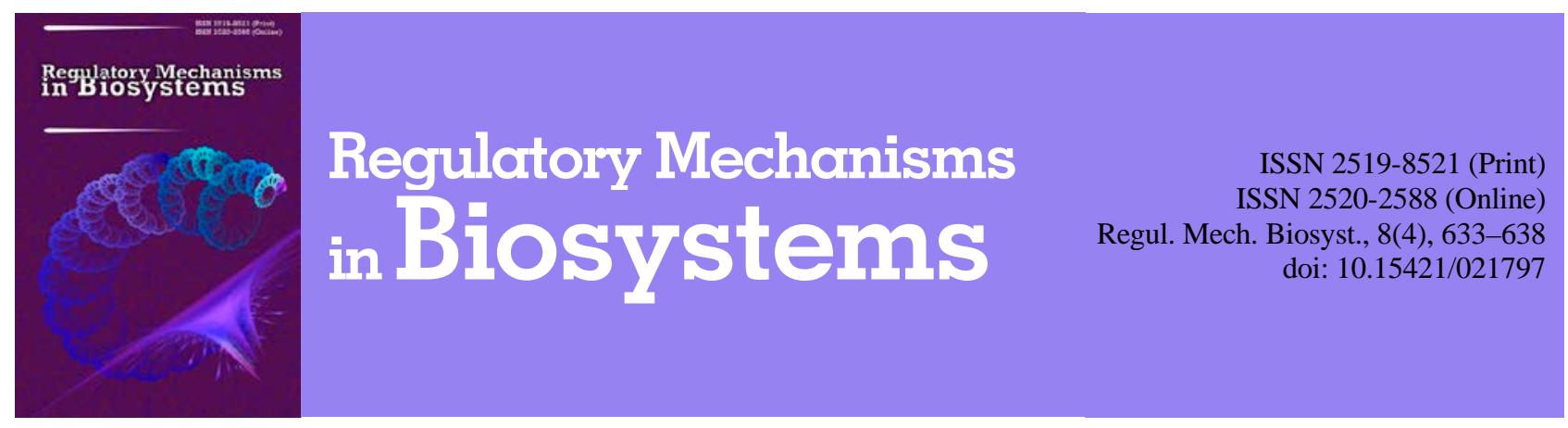

\title{
Post-pyrogenic changes in vegetation cover and biological soil crust in steppe ecosystems
}

\author{
V. V. Shcherbyna*, I. A. Maltseva**, Y. I. Maltsev**, A. N. Solonenko** \\ *Tavria State Agrotechnological University, Melitopol, Ukraine \\ **Melitopol Bohdan Khmelnytskyi State Pedagogical University, Melitopol, Ukraine
}

Article info

Received 26.09.2017

Received in revised form 07.11.2017

Accepted 14.11.2017

Tavria State Agrotechnological University, B.Khmelnytskyi Ave., 18, Melitopol, 72310, Ukraine.

Melitopol Bohdan Khmelnytskyi State Pedagogical University, Hetmanska str., 20, Melitopol, 72312, Ukraine.

Tel.: +38-097-506-25-20.

E-mail: shcherbyna_vv@ukr.net

\begin{abstract}
Shcherbyna, V. V., Maltseva, I. A., Maltsev, Y. I., \& Solonenko, A. N. (2017). Post-pyrogenic changes in vegetation cover and biological soil crust in steppe ecosystems. Regulatory Mechanisms in Biosystems, 25(4), 633-638. doi:10.15421/011797
\end{abstract}

The study of the processes of restoration of species richness and productivity of steppe ecosystems after fires is an urgent problem that affects not only the conservation of biodiversity but also the maintenance of pasture resources. This article presents the results of a study of post-pyrogenic effects in steppe ecosystems, taking into account changes in the species composition of cyanoprokaryotes and algae that are art of the biological soil crust, which performs ecologically important functions in xerophytic ecosystems. The investigations were carried out in virgin and postpyrogenic steppe ecosystems of the “Troitsk Clough" reserve (Zaporizhia region, Ukraine). For three years, the dynamics of the projective cover and the height of the vegetation cover in virgin areas of herbs-fescue-feather-grass and fescue-feather-grass steppes was studied as well as within two ecosystems of post-pyrogenic development after fires that occurred in the spring and winter periods. We discovered that restoration of the herbs-fescue-feather-grass and fescue-feather-grass steppes after fires occurs at different rates. The cause of the slow restoration of vegetation cover can be its severe damage by fire at the beginning of the vegetation season and the development of erosion processes. The number of species of cyanoprokaryotes and algae in the biological soil crust of virgin and post-pyrogenic ecosystems is not significantly different. It varies from 35 to 49 species. The greatest diversity is noted for Cyanoprokaryota. Chlorophyta is in the second place. Among the dominants, the filamentous forms of Cyanoprokaryota prevail. Nostoc edaphicum was noted as a nitrogen fixing representative. The similarity of the species lists of cyanoprokaryotes and algae of post-pyrogenic and virgin ecosystems, according to the calculated Jaccard coefficient, varies from $49.1 \%$ to $55.3 \%$. This indicates a strong specificity of the composition of cyanoprokaryotes and algae in post-pyrogenic biological soil crusts. Changes in their composition reflect different stages of post-pyrogenic succession. In the first year after a fire, there is a slight increase in species richness, which is a consequence of the favorable effect of increasing the amount of mineral substances in the soil after the organic matter has burned out. The "pioneer" group includes: Phormidium autumnale, Ph. dimorphum, Ph. retzii, Ph. (Leptolyngbya) henningsii, Luticola mutica, Hantzschia amphioxys. Gradually this effect is leveled and the species richness of cyanoprokaryotes and algae is stabilized at a level peculiar for this type of ecosystem.

Keywords: steppe; fire; algae; cyanoprokaryotes; projective cover; biological soil crust; post-pyrogenic succession

\section{Introduction}

Fires in ecosystems formed by grasses is a fairly common phenomenon associated with the effects of natural and anthropogenic factors (Kolomiiets and Burda, 2007; Scheintaub et al., 2009; Clark et al., 2016). The study of the processes of restoration of their species richness and productivity after fires is a relevant problem considering the interests of not only the conservation of biodiversity but also the maintenance of pasture resources.

It is believed that the pyrogenic factor has a significant influence on the formation and evolution of the grass ecosystems, directing the natural selection to increase the fire resistance of biological diversity, the ability to quickly and most effectively use the changed environmental conditions (salinity of the soil cover, hydrothermal and geochemical regimes, etc.) for recovery, growth and development (Lysenko, 2008; Cleary et al., 2010; Buc, 2012). Changes that occur after fires in grass ecosystems have become the basis for working out the models with different scenarios of vegetation burning to control the productivity and species composition of pasture vegetation (Allen et al., 2011; Strong et al., 2013; Fonseca et al., 2017).

The occurrence and spread of fire leads to changes in all components of ecosystems. Their recovery is realized by successive digressive-demutational changes, the study of which has received considerable attention (Kolomiiets and Burda, 2007; Havrylenko, 2011; Buc, 2012). Y. Odum singles out the changes of ecosystems after a fire in a separate group of post-pyrogenic successions, calling them "pulsating stable successions". Peculiarities of pyrogenic changes and demutational processes are caused both by the specifics of ecosystem components and by the scale, intensity, time of occurrence of fires and other factors (Scherbina et al., 2014; Savadogo et al., 2017).

In the literature, there is a lot of data on the analysis of postpyrogenic transformations of soil (Vermeire et al., 2011; Rau et al., 2014; Qi et al., 2017), phytocenoses (Tooth and Leishman, 2013; Reed-Dustin et al., 2016), zoocenoses (Mordkovich et al., 2007; Morgun, 2010). The changes that occur in coenoses of soil microorganisms under the influence of fires, including algae communities (Chumacheva, 2001; 
Myers and Davis, 2003; Pivovarova and Chumacheva, 2004) are much less studied. The latter are considered as an integral part of biological soil crusts, performing important ecological functions in grass ecosystems and, especially, in their xerophytic variants (Maestre et al., 2002; Belnap, 2002; Dettweiler-Robinson et al., 2013).

Soil algae and cyanoprokaryotes are pioneers of settling intrusions. Therefore, they can be the indicators of processes occurring in ecosystems immediately after fires and reflect the dynamics of their restoration from pyrogenic transformation. The data, obtained during the research presented in this article can be used in subsequent studies of postpyrogenic territories, working out the scenarios of controlling their productivity and biodiversity processes. The aim of our research was to study post-pyrogenic effects in steppe ecosystems, taking into account the changes in the species composition of cyanoprokaryotes and algae included in the biological soil crust composition.

\section{Materials and methods}

Steppe ecosystems have been preserved in the territory of Ukraine mainly in protected areas. For their protection, a variety of different modes are used: from creation of strict nature reserve creation to the use of natural steppe areas as hayfields and for grazing. Our study of postpyrogenic changes was conducted on the steppe plots of the local reserve "Troitsk Clough" (Zaporizhia region, Ukraine) under the conditions of herbs-fescue-feather-grass steppe (PP 1) and fescue-feathergrass steppe (PP 2) as well as within two ecosystems of post-pyrogenic development following 2009 (PP 3) and 2010 (PP 4) fires over 3 years in different seasons of the year. To evaluate post-pyrogenic changes, the projective cover and height of vegetation cover of virgin steppe and post-pyrogenic areas were investigated. To study the composition of cyanoprokaryotes and algae in the biological soil crust of steppe ecosystems, soil samples were selected in compliance with all requirements for microbiological studies. The methodology proposed by M. M. Golerbach and E. A. Shtyna (1969) was applied. Determining species composition of algae and cyanoprokaryotes was performed by using an optical microscope XSP-128V (lens 4x, 10x, 40x, 100x) involving the following culture methods: method of ground crops with glasses fouling batch culture, method of enrichment cultures on agar nutrient environment and method of pure cultures (Kostikov et al., 2001). Allologically pure cultures were defined by using a stereoscopic microscope MBS 1 .

Identifying the species belonging to the algae of the Cyanoprocaryota (Cyanophyta), Chlorophyta, Xanthophyta and Eustigmatophyta groups was realized through the study of living cultures, which helped to determine identifiably significant characteristics of the algae of corresponding groups. Cytochemical reactions were used if needed. The research is based on the system of falgae classificatio, which is proposed in the monograph "Algae of Soils of Ukraine: History and Methods of Research, System, Constellation of Flora” (Kostikov et al., 2001).

On the basis of the cultures with fouling glasses, which are considered to be the closest to natural conditions, the dominants and the subdominants were determined by using a seven-point scale of abundance. The species with abundance score of 7 and 6 were considered to be dominants. The obtained data were analyzed by using the methods of comparative floristics. Mathematical analysis of the study results was conducted in Statistica 6.0 (StatSoft Inc., USA).

\section{Results}

Within the local reserve "Troitsk Clough" the plots of herbs-fescuefeather-grass and fescue-feather-grass steppes two sample plots PP 1 and PP 2 were selected as reference areas. The studied ecosystems differed in composition, projective cover, height of high altitude vegetation and were located at the top part of a slope of the northern exposure (Table 1). There is no step-bed. There is occurence of water erosion of the soil.

\section{Table 1}

Projective cover and height of vegetation cover of etalon and post-pyrogenic ecosystems of the reserve "Troitsk Clough" in the years and seasons of the study $(\mathrm{M} \pm \mathrm{m}, \mathrm{n}=6)$

\begin{tabular}{|c|c|c|c|c|c|c|c|}
\hline \multirow{2}{*}{ Criteria } & 2009 & \multicolumn{3}{|c|}{2010} & \multicolumn{3}{|c|}{2011} \\
\hline & autumn & spring & summer & autumn & spring & summer & autumn \\
\hline \multicolumn{8}{|c|}{ PP 1. Virgin steppe. Herbs-fescue-feather-grass } \\
\hline Projective cover, $\%$ & $71.3 \pm 4.1$ & $69.1 \pm 3.2$ & $68.6 \pm 3.9$ & $72.3 \pm 2.5$ & $69.3 \pm 2.9$ & $69.2 \pm 2.2$ & $70.8 \pm 4.2$ \\
\hline Height of vegetation cover, $\mathrm{cm}$ & $80.0 \pm 5.9$ & $90.2 \pm 11.3$ & $70.2 \pm 4.3$ & $95.6 \pm 6.8$ & $80.3 \pm 5.1$ & $60.7 \pm 3.7$ & $82.3 \pm 4.1$ \\
\hline \multicolumn{8}{|c|}{ PP 2, Virgin steppe. Fescue- feather-grass steppe } \\
\hline Projective cover, \% & $59.5 \pm 3.1$ & $60.6 \pm 4.2$ & $62.2 \pm 2.2$ & $54.2 \pm 3.7$ & $69.3 \pm 6.5$ & $54.3 \pm 4.2$ & $58.6 \pm 4.7$ \\
\hline Height of vegetation cover, $\mathrm{cm}$ & 65.15 .1 & $60.9 \pm 4.7$ & $73.6 \pm 9.6$ & $72.8 \pm 4.8$ & $55.3 \pm 3.7$ & $68.9 \pm 7.8$ & $59.3 \pm 3.5$ \\
\hline \multicolumn{8}{|c|}{ PP 3. Virgin steppe. Post-pyrogenic succession of winter fire in 2009} \\
\hline Projective cover, \% & $42.3 \pm 6.2$ & $70.3 \pm 5.2$ & $68.6 \pm 4.7$ & $72.3 \pm 4.7$ & $69.3 \pm 4.2$ & $69.2 \pm 5.7$ & $70.8 \pm 6.2$ \\
\hline Height of vegetation cover, $\mathrm{cm}$ & $63.0 \pm 3.7$ & $90.3 \pm 5.0$ & $70.2 \pm 8.4$ & $95.6 \pm 9.3$ & $80.3 \pm 4.5$ & $60.7 \pm 3.6$ & $82.3 \pm 7.1$ \\
\hline \multicolumn{8}{|c|}{ PP 4. Virgin steppe. Post-pyrogenic succession of spring fire in 2010} \\
\hline Projective cover, \% & $-*$ & 0 & $6.2 \pm 0.5$ & $10.6 \pm 1.8$ & $10.8 \pm 1.6$ & $12.3 \pm 0.8$ & $10.1 \pm 0.7$ \\
\hline Height of vegetation cover, $\mathrm{cm}$ & - & 0 & $22.3 \pm 2.7$ & $26.8 \pm 3.1$ & $28.7 \pm 2.7$ & $25.3 \pm 3.0$ & $24.6 \pm 3.7$ \\
\hline
\end{tabular}

Note: $\mathrm{M}$ - arithmetic mean; $\mathrm{m}$ - error of arithmetic mean; $\mathrm{n}$ - general sampling; * - research was not realized.

According to the principle of geobotanical zoning, the researched object of Ukraine's nature reserve fund lies within the Euro-Asian steppe region, the Black Sea steppe province, Priazovsko-Black Sea steppe subprovince in the band of fescue-feather grass steppes. Fescuefeathergrass steppes are characterized by a predominance of xerophilic turf grasses with poor xerophilic grasses of such typical species as Ferula orientalis L., Verbascum phoeniceum L., Carduus uncinatus Bieb., Tanacetum millefolium (L.) Tzvel and others.

The higher vegetation flora of "Troitsk Clough" numbers about 450 species. Its territory is dominated by steppe vegetation (class Festuco-Brometea) with domination of Stipa lessingiana Trin. et Rupr., Stipa capillata L., Stipa ucrainica P. Smirn, Agropyron pectinatum (Beib.) Beauv., Festuca valesiaca Gaud. The site is one of the most important localities in Ukraine for Calophaca wolgarica (L. fil.) DC, Cymbochasma borysthenica (Pall. ex Schlecht.) Klok. et Zoz, Allium pervestitum Klok., Elytrigia stipifolia (Czern. ex Nevski) Nevski, Caragana scythica (Kom.) Pojark, Centaurea talievii Kleopow, Astragalus pallescens Bieb., Eremogone rigida (M. Bieb.) Fenzl. Many other rare species grow there, including endemic ones: Bellevala sarmatica (Georgi) Woronow (forms fragments of groupings), Dianthus carbonatus Klokov, D. guttatus Beib, D. platyodon Klok, Minuartia leiosperma Klok, Stipa ucrainica, Veronica sclerophylla. Kotov. Significant populations on the steppe part of the clough are formed by Adonis vernalis L. (Kolomiichuk et al., 2012).

Within the territory of the reserve, the strict nature reserve regime has not been introduced, therefore it is used by the local population as a pasture, which, along with fires, creates additional threats to biodiversity and productivity. According to the results of the conducted studies in PP 1 in the composition of biological soil crusts, 38 species of algae and cyanoprokaryotes were identified, belonging to 5 groups: Cyanoprokaryota - 21 (55.3\%), Eustigmatophyta - 1 (2.6\%), Xanthophyta - 1 (2.6\%), Bacillariophyta - 6 (15.8\%) and Chlorophyta - 9 species (23.7\%).

The leading families are Phormidiaceae (10 species), Pseudanabaenaceae (6) and Bacillariaceae (3), which combine $50.0 \%$ of the group. The special attention should be given to the genera: Phormidium Kützing ex Gomont (10 species), Leptolyngbya Anagnostidis et Komarek 
(5), Nostoc Vaucher exBornet et Flahault (3) and Nitzschia Hassal (2). Dominant among cyanoprokaryotes and eukaryotic algae in the biological soil crust were: Phormidium valderiae (Delp.) Geitler, Ph. bohneri Schmidle, Leptolyngbya foveolarum (Rabenhorst ex Gomont) Anagnostidis et Komarek, Nostoc edaphicum Kondratyeva, Leptosira terricola (Bristol) Printz, Bracteacoccus minor (Chodat) Petrova and Heterococcus viridis Chodat.

In biological soil crust of ecosystem of the fescue-feather grass steppe (PP 2), 35 species of 5 groups were identified: Cyanoprocaryota 20 (57.1\%), Eustigmatophyta - 1 (2.9\%), Xanthophyta - 2 (5.7\%), Bacillariophyta $-6(17.1 \%)$ and Chlorophyta -6 species (17.1\%). The leading families include Phormidiaceae (11 species), Pseudanabaenaceae (5) and Bacillariaceae (3), which combine $54.3 \%$ of the species of the group. The leading genera are: Phormidium (11 species), Leptolyngbya (5), Nostoc, Chlorococcum Meneghini and Nitzschia (2 species).

The dominants included Eustigmatos magnus (Petersen) Hibberd, Heterococcus viridis, Phormidium autumnale (Agardh) Gomont, Ph. (Leptolyngbya) henningsii Lemmermann, Leptolyngbya foveolarum (Rabenhorst ex Gomont) Anagnostidis et Komarek, Nostoc edaphicum, Hantzschia amphioxys (Ehrenberg) Grunow in Celeve et Grunow, Bracteacoccus minor.

In total, within the reference geobiocoenosis of the local reserve "Troitsk Clough" in biological soil crusts there were identified 49 species of cyanoprokaryotes and eukaryotic algae that belonged to 5 groups: Cyanoprocaryota - 27 (55.1\%), Eustigmatophyta - 2 (4.1\%), Xanthophyta - 2 (4,1\%), Bacillariophyta - 6 (12.2\%) and Chlorophyta - 12 species (24.5\%). In the composition of biological soil crusts of etalon ecosystems, about $30 \%$ of the species composition is formed by representatives of the family Phormidiaceae. The number of species in the families Pseudanabaenaceae and Bacillariaceae, belonging to the leading ones in the abovementioned biological soil crust is close.

In the local reserve "Troitsk Clough", the study of two geobiocoenoses of post-pyrogenic development from fires in 2009 (PP 3) and 2010 (PP 4) was conducted. The relevant sites were on the slope of the northern (PP 4) and southern exposure (PP 3). The studied ecosystems differed in composition, projective cover, height of higher vegetation (Table 1). 35 species of algae and cyanoprokaryotes from 5 groups were identified in the biological soil crusts composition on the PP 3 , which was laid on the territory of the geobiocoenoses of post-pyrogenic development from the fire in 2009: Cyanoprocaryota - 20 species (57.1\%), Eustigmatophyta - 1 (2.9\%), Xanthophyta - 1 (2.9\%), Bacillariophyta 5 (14.3\%) and Chlorophyta - 8 (22.9\%). The leading families include Phormidiaceae (11 species), Pseudanabaenaceae (6), Chlorococaceae and Bacillariaceae (3 species of each), which combine $65.7 \%$ of species. Among the leading genera are Phormidium (11 species), Leptolyngbya (5), Chlorococcum and Nitzschia (2 species in each). The dominant species of post-pyrogenic biological soil crust among algae and cyanoprocariots in this plot were the following: Heterococcus viridis, Phormidium retzii (Agardh) Gomont, Phormidium paulsenianum B. Petersen, Ph. bohneri, Leptolyngbya foveolarum, Chlorococcum chlorococcoides (Korschikov) Philipose, Eustigmatos magnus.

On the territory of the ecosystem of post-pyrogenic development from the fire in 2010 (PP 4) 41 species of algae from 5 groups were noted in the composition of biological soil crust: Cyanoprocaryota - 22 (53.7\%), Eustigmatophyta - 1 (2.4\%), Xanthophyta - 2 (4.9\%), Bacillariophyta -6 (14.6\%) and Chlorophyta - 10 (24.4\%). The leading families are Phormidiaceae (11 species), Pseudanabaenaceae (6), Bacillariaceae, Naviculaceae (3 species in each) and Chlorosarcinaceae (2) within the area of post-pyrogenic development and combine $61.0 \%$ of species. The leading genera are Phormidium (11 species), Leptolyngbya (4), Nostoc (3), Chlorosarcinopsis Herndon and Nitzschia (2 species in each).

The dominants were represented by the species Heterococcus viridis, Phormidium retzii, Ph. (Leptolyngbya) henningsii, Leptolyngbya foveolarum, Leptolyngbya fragilis (Gomont) Anagnostidis et Komarek, Nostoc edaphicum, Parietochloris pseudoalveolaris (Deason et Bold) Watanabe et Floyd in Deason et al., Eustigmatos magnus. 51 species of algae and cyanoprokaryotes belonging to five groups: Cyanoprocaryota 25 (49.1\%), Eustigmatophyta - 1 (1.9\%), Xanthophyta - 2 (3.9\%), Bacillariophyta - 6 (11.8\%) and Chlorophyta - 17 (33.3\%) were recor- ded overall in the biological soil crusts of post-pyrogenic ecosystems of “Troitsk Clough" reserve.

The calculated Jaccard index of commonality for the complete algal species list indicates an average specificity of the algae composition of the studied ecotopes in the post-pyrogenic and etalon ecosystems of the “Troitsk Clough" reserve (Table 2).

\section{Table 2}

Similarity of species composition of algae groups in different ecosystems according to the community coefficient of Jaccard

\begin{tabular}{lcccc}
\hline Sampling area & PP 1 & PP 2 & PP 3 & PP 4 \\
\hline PP 1 & 38 & 52.1 & 55.3 & 49.1 \\
PP 2 & 25 & 35 & 52.2 & 55.1 \\
PP 3 & 26 & 24 & 35 & 49.0 \\
PP 4 & 26 & 27 & 25 & 41 \\
\hline
\end{tabular}

Note: diagonally - the number of species in the group, in the upper corner the value of the community of Jaccard coefficient, in the lower corner - the number of common species in the comparable groups.

\section{Discussion}

The restoration of steppe ecosystems after fires in general occurs according to the scenario typical for other ecosystems formed by grasses. A number of researchers note an increase in the productivity of grass ecosystems after a fire (Limb et al., 2016; Gates et al., 2017). There is information about increasing the participation of perennial grasses and reducing annual grasses, the positive response of legumes (Scheintaub et al., 2009). At the same time, evaluating the consequences of fires for grass ecosystems is not single-valued. The positive effect in post-pyrogenic changes may be absent. In most cases, negative manifestations are limited within a two-year period (Limb et al., 2016; Gates et al., 2017). Fire, combined with subsequent grazing, can lead to the disappearance of the most sensitive plant species (Clark et al., 2016). Therefore, outside well-studied ecosystems, the application of the obtained results should be restricted. This should be taken into account in the case of the planned burning out of grass ecosystems in order to increase their productivity (Scheintaub et al., 2009; Allen et al., 2011; Miller et al., 2017). The consequences of uncontrolled fires for an ecosystem depend on the season of the fire, its scale, intensity, frequency etc. (Ford and Johnson, 2006; Strong et al., 2013; Scherbina et al., 2014).

The investigated post-pyrogenic steppe ecosystems have a different rate of restoration of the projective cover by higher plants (Table 1 ). If in the plot PP 3 after the winter fire there was a rapid restoration to the virgin steppe indicators, then in PP 4, this process was very slow. The reason for the slow restoration of vegetation cover can be its severe damage by fire at the beginning of vegetation and the development of erosion processes. The high sensitivity of perennial grasses to fires during the growing season is also noted by Ford and Johnson (2006). Restoration processes of vegetation cover after fires occur simultaneously with the renewal of soil functions, vital activity of soil microorganisms and organisms in biological soil crusts (Liu et al., 2010; Limb et al., 2016).

In steppe ecosystems, as well as in other xerophytic ecosystems, biological soil crusts often are created on or below the soil surface (Langhans et al., 2010). They include cyanoprokaryotes, eukaryotic algae, mosses, lichens and fungi that connect soil particles. The thickness of such crusts is usually measured in several millimeters. Some types of filamentous cyanoprokaryotes can permeate the topsoil to a depth of $10 \mathrm{~cm}$ (Belnap and Gardner, 1993), increasing the thickness of the crust. It is known that the spread of algae and cyanoprokaryotes in the soil is not limited to this depth. Their living cells have been found at the depth of $120 \mathrm{~cm}$ (Maltseva and Pysanets 2004; Shekhovtseva and Maltseva 2015; Maltseva et al., 2017) and more (Gollerbah and Shtina, 1969). They are diffusely dispersed along the soil profile and cannot perform functions peculiar to biological soil crust.

The results of the latest research on algae and cyanoprokaryotes of virgin steppe ecosystems in Ukraine are reported in the works Maltseva (2003), Maltseva and Pisanets (2004), Baranova et al. (2009), Baranova and Maltseva (2009), Shcherbyna (2014, 2015), Maltseva and Shcherbyna (2011), Shcherbyna et al. (2014). This work has contributed to the 
preliminary evaluation of the species richness of algae and cyanoprokaryotes of zonal and azonal soils, description of new areas of rare and widespread algae species, updated and supplemented existing data.

Many printed works are devoted to the ecology-coenological direction and contain information about the peculiarities of algae and cyanoprokaryotes of the steppe zone, whose dynamics are observed in accordance with soil conditions, the type of vegetation and other components and elements of ecosystems. In general, the features of the floral composition of algae and cyanoprokaryotes of zonal steppe ecosystems have been defined on the territory of Ukraine (Kostikov et al., 2001; Chumacheva, 2001; Pivovarova and Chumacheva 2004), as well as beyond its borders. One more direction has been presented by the study of algae and cyanoprokaryotes in the composition of biological soil crusts (Belnap, 2002; Ford and Johnson 2006; Langhans et al., 2009). It was found that the formation of biological soil crust on the soil surface of xerophytic ecosystems is carried out in stages (Dettweiler-Robinson et al., 2013). Cyanoprokaryotes and eukaryotic algae appear first, then lichens and mosses do. When destruction occurs, the rate of biological soil crust restoration differs. Crusts are most quickly restored after fires (Myers and Davis, 2003). This is confirmed by our research. On the plot burnt in the spring of 2010, in the summer period the species of Cyanoprocaryota, Bacillariophyta and isolated species of Chlorophyta were already observed. The "pioneer" group includes: Phormidium autumnale, Ph. dimorphum Lemmermann, Ph. retzii, Ph. (Leptolyngbya) henningsii, Luticola mutica Kutzing Mann in Round et al., Hantzschia amphioxys. The appearance of higher plants did not compensate the severe ecotopic conditions and did not contribute to the rapid increase in the diversity of cyanoprokaryotes and algae. The maximum species richness was noted in the spring of the second year after the fire. In general, the diversity of species of algae and cyanoprokaryotes reaches the highest values in the first two years after a fire and then decreases to values peculiar to the virgin steppe. In the initial period after a fire, the active development of algae and cyanoprokaryotes is facilitated by the appearance of easily accessible mineral compounds after the organic mass burning out, by the absence of shading from higher plants and steppe litter. Gradually this effect fades away; the species diversity of algae and cyanoprokaryotes is established in a range typical for this type of ecosystem. In our studies, the most susceptible to soil sod formation were Cyanoprocaryota (the correlation coefficient varied from -0.861 to -0.947 ).

In the study of biological soil crusts, as Tanja Margrit Langhans and co-authors (2010) note, the species composition analysis of the organisms that make up their composition is very rarely done. This limits the possibility of interpreting the obtained data. In our research the similarity of the algae and cyanoprokaryotes in biological soil crust species lists of post-pyrogenic and etalon ecosystems of the "Troitsk Clough" reserve is $49.0 \%$ by the value of the Jaccard coefficient, which confirms the average indicators of their similarity (Table 2).

According to the taxonomic structure of algae and cyanoprokaryotes, the etalon ecosystems are very similar to the post-pyrogenic ones. Cyanoprocaryota prevail in all of them without exception. The share of algae of the groups Eustigmatophyta, Xanthophyta and Bacillariophyta is almost unchanged. Green algae occupy the second place by number of species. Families of Phormidiaceae, Pseudanabaenaceae and Bacillariaceae are among the leading both in virgin areas and in postpyrogenic geobiocoenoses. The return of the Nostoc genus to the list of leading genera on the area of post-pyrogenic restoration after the 2010 fire is in line with the results of studies by other authors, who during the study of the effects of fires on the state of microbiocenoses of the soil indicated the increase in the number of microorganisms in the nitrogen cycle: mineral nitrogen immobilizers, oligonitrophils, denitrification agents (Malinovskaia, 2012). They associated it with the entry of mineral substances into the soil after the fire. The results of algae studies of post-pyrogenic areas also indicate the activation of nitrogen-fixing Cyanoprocaryota (Pivovarova and Chumacheva, 2001).

The restoration of biological soil crust in xerophytic ecosystems is of great importance for their functioning. A fire occurring not in the vegetation season has a slight effect on perennial grasses, but maximally destroys the biological soil crusts. Their destruction worsens soil resistance to wind and water erosion (Hu et al., 2002; Bowker et al., 2004;
Zhang et al., 2006; Jimenez-Aguilar et al., 2009), accompanied by loss of $\mathrm{C}$ and $\mathrm{N}$ due to water erosion (Barger et al., 2006) and a reduction in humus content (Langhans et al., 2010).

The studied ecosystems (both virgin and post-pyrogenic) are located on slopes. The increase in the diversity of algae and cyanoprokaryotes in the early stages of the formation of biological soil crust occurred against the background of overcoming the phenomena of flushing. The main role in fixing the surface of the soil was played by filamentous species of Cyanoprocaryota. Their anti-erosion role is shown in other ecosystems as well (Hu et al., 2002; Bowker et al., 2004; JimenezAguilar et al., 2009).

Another interesting effect of the absence in the first stages of postpyrogenic successions and the gradual formation of a typical biological soil crust for a particular ecosystem is the influence of biological soil crusts on seed germination and emergence (Langhans et al., 2009). It is indicated that the biological soil crusts can influence the penetration of seeds into deep soil layers, promote emergence by means of increasing moisture, nutrient content (Maestre et al., 2002; Liu et al., 2006). There is also evidence that biological soil crust may act as an inhibitor to higher plants (Escudero et al., 2007). The role of each of the components of biological soil crusts in the manifestation of these effects has not been sufficiently studied. Concerning cyanoprokaryotes that are part of the biological soil crust, it is known that some of them are capable of activating the beneficial and inhibiting the pathogenic microflora, altering the fermentative activity of the soil, etc., thereby stimulating the germination of the seeds of higher plants (Maltsev, 2015; Maltsev et al., 2017).

Taking this into account, it can be assumed that post-pyrogenic successions of higher plants and organisms that make up the biological soil crusts are coordinated and interdependent. Detailed study of this issue will allow us to reach a new level of control of restoration processes in post-pyrogenic ecosystems.

\section{Conclusions}

Restoration of the herbs-fescue-feather-grass and fescue-feather-grass steppes after fire occurs at different rates. The cause of the slow restoration of vegetation cover can be its severe damage by fire at the beginning of the vegetation season and the development of erosion processes.

The surface layer of the soil of virgin and post-pyrogenic steppe ecosystems is populated by cyanoprokaryotes and eukaryotic algae. They are the part of the biological soil crust, which performs important ecological functions in xerophytic steppe ecosystems: it increases the erosion resistance of the soil surface, enriches the soil with organic matter, increases the nitrogen content in the soil due to nitrogen fixation, affects the germination of seeds, etc.

The number of species of cyanoprokaryotes and algae in biological soil crusts of virgin and post-pyrogenic ecosystems is not significantly different. It varies from 35 to 49 species. The greatest diversity is noted for Cyanoprocaryota. Chlorophyta is in the second place. Among the dominants, the filamentous forms of Cyanoprocaryota prevail. Nostoc edaphicum was noted as a nitrogen fixing representative.

The similarity of the species lists of cyanoprokaryotes and algae of post-pyrogenic and virgin ecosystems, according to the calculated Jaccard coefficient, varies from 49.1 to $55.3 \%$. This indicates a strong specificity of the composition of cyanoprokaryotes and algae in post-pyrogenic biological soil crust. Changes in their composition reflect different stages of post-pyrogenic succession. In the first year after the fire, there is a slight increase in species richness, which is a consequence of the favorable effect of increasing the amount of mineral substances in the soil after the organic matter has burned out. The "pioneer" group includes: Phormidium autumnale, Ph. dimorphum, Ph. retzii, Ph. (Leptolyngbya) henningsii, Luticola mutica, Hantzschia amphioxys. Gradually this effect is leveled and the species richness of cyanoprokaryotes and algae is stabilized at a level peculiar for this type of ecosystem.

\section{References}

Allen, E. B., Steers, R. J., \& Dickens, S. J. (2011). Impacts of fire and invasive species on desert soil ecology. Rangeland Ecology and Management, 64(5), 450-462. 
Baranova, O. O., \& Maltseva, I. A. (2009). Gruntovi vodorosti khvostoskhovyshcha ta prylehlykh terytorii na Kryvorizhzhi [Soil algae of tailing dumps and adjacent territories of Kryvbas]. Gruntoznavstvo, 10(3-4), 93-98 (in Ukrainian).

Baranova, O. O., Kvitko, M. O., \& Maltseva, I. A. (2009). Alhouhrupovannia stepovykh fitotsenoziv zakaznyka "Balka Pivnichna Chervona” na Kryvorizhzhi [Algae groups of steppe phytocoenoses of reserve "Gorge north red" of Kryvbas]. Visnyk Harkivs’kogo Nacional’nogo Agrarnogo Universytetu. Seriia Biolohiia, 1, 106-110 (in Ukrainian).

Barger, N. N., Herrick, J. E., Van Zee, J., \& Belnap, J. (2006). Impacts of biological soil crust disturbance and composition on $\mathrm{C}$ and $\mathrm{N}$ loss from water erosion. Biogeochemistry, 77, 247-263.

Belnap, J. (2002). Impacts of off-road vehicles on nitrogen cycles in biological soil crusts: Resistance in different U. S. deserts. Journal of Arid Environments, 52(2), 155-165.

Belnap, J., \& Gardner, J. S. (1993). Soil microstructure in soils of the Colorado Plateau: The role of the cyanobacterium Microcoleus vaginatus. The Great Basin Naturalist, 53(1), 40-47.

Bowker, M., Belnap, J., Rosentreter, R., \& Graham, B. (2004). Wildfire-resistan biological soil crusts and fire-induced loss of soil stability in Palouse prairies, USA. Applied Soil Ecology, 26(1), 41-52.

Buc, J. V. (2012). Pirogenna relaksija geosistem [Pyrogenic relaxation of geosystems]. Ljudina ta dovkillja. Problemi Neoekologii, 1-2, 71-76 (in Ukrainian).

Chumacheva, N. M. (2001). Strategija vosstanovlenija al'gogruppirovok posle nizovogo pozhara [The starategy of algae groupings remediation after the creeping fire]. Sibirskij Ekologicheskij Zhurnal, 4, 449-454 (in Russian).

Clark, P. E., Williams, C. J., Pierson, F. B., \& Hardegree, S. P. (2016). Postfire grazing management effects on mesic sagebrush-steppe vegetation: Spring grazing. Journal of Arid Environments, 132, 49-59.

Cleary, M. B., Pendall, E., \& Ewers, B. E. (2010). Aboveground and belowground carbon pools after fire in mountain big sagebrush steppe. Rangeland Ecology and Management, 63(2), 187-196.

Dettweiler-Robinson, E., Bakker, J. D., \& Grace, J. B. (2013). Controls of biological soil crust cover and composition shift with succession in sagebrush shrub-steppe. Joumal of Arid Environments, 94, 96-104.

Escudero, A., Martinez, I., de la Cruz, A., Otalora, M. A. G., \& Maestre, F. T. (2007). Soil lichens have species-specific effects on the seedling emergence of three gypsophile plant species. Journal of Arid Environments, 70, 18-28.

Fonseca, F., Figueire, T., Nogueira, C., \& Queiros, A. (2017). Effect of prescribed fire on soil properties and soil erosion in a mediterranean mountain area. Geoderma, 300, 172-180.

Ford, P. L., \& Johnson, G. V. (2006). Effects of dormant-vs. growing-season fire in shortgrass steppe: Biological soil crust and perennial grass responses. Journal of Arid Environments, 67(1), 1-14.

Gates, E. A., Vermeire, L. T., Marlow, C. B., \& Waterman, R. C. (2017). Fire and season of postfire defoliation effects on biomass, composition, and cover in mixed-grass prairie. Rangeland Ecology and Management, 70(4), 430-436.

Gollerbah, M. M., \& Shtina, E. A. (1969). Pochvennyie vodorosli [Soil algae]. Nauka, Leningrad (in Russian).

Havrylenko, V. S. (2011). Systema zapobihannia stepovykh pozhezh, prychyny yikh vynyknennia ta sposoby hasinnia v Biosfernomu zapovidnyku "Askaniia-Nova” [A system of prevention of steppe fires, origin of the fires and methods of fire extinguishing in the biosphere reserve "Askania-Nova"] Visti Biosfernoho Zapovidnyka Askaniia-Nova, 13, 64-77 (in Ukrainian).

Hu, C. X., Liu, Y. D., Song, L. R., \& Zhang, D. L. (2002). Effect of desert soil algae on the stabilization of fine sands. Journal of Applied Phycology, 14(4), 281-292.

Jimenez-Aguilar, A., Huber-Sannwald, E., Belnap, J., Smart, D. R., \& ArredondoMoreno, J. T. (2009). Biological soil crusts exhibit a dynamic response to seasonal rain and release from grazing with implications for soil stability. Journal of Arid Environments, 73(12), 1158-1169.

Kolomiichuk, V. P., Onyshchenko, V. A., \& Perehrym, M. M. (2012). Vazhlyvi botanichni terytorii Pryazovia [Important botanical areas of the Azov Sea region]. Alterpres, Kyiv (in Ukrainian).

Kolomiiets, H. V., \& Burda, R. I. (2007). Postpirohenni demutatsii ekosystem nadrichkovykh piskiv na Mykolaivshchyni [Post-pyrogenic de-mutation of tributary sands ecosystems in Mykolaiv region]. Naukovyi Visnyk Natsionalnoho Ahrarnoho Universytetu, 117, 34-41 (in Ukrainian).

Kostikov, I. Y., Romanenko, P. O., Demchenko, E. M., Dariyenko, T. M., Myhajlyuk, T. I., Rybchynskyj, O. V., \& Solonenko, A. M. (2001). Vodorosti hruntiv Ukrainy: Istoriia ta metody doslidzhen, systema, konspekt flory. Fitosotsiotsentr, Kyiv (in Ukrainian).

Langhans, T. M., Storm, C., \& Schwabe, A. (2009). Biological soil crusts and their microenvionment: Impact on emergence, survival and establishment of seedlings. Flora - Morphology, Distribution, Functional Ecology of Plants, 204(2), 157-168

Langhans, T. M., Storm, C., \& Schwabe, A. (2010). Regeneration processes of biological soil crusts, macro-cryptogams and vascular plant species after finescale disturbance in a temperate region: Recolonization or successional replacement? Flora - Morphology, Distribution, Functional Ecology of Plants, 205(1), 46-60.

Limb, R. F., Fuhlendorf, S. D., Engle, D. M., \& Miller, R. F. (2016). Assessment of research on rangeland fire as a management practice. Rangeland Ecology and Management, 69(6), 415-422.

Liu, W. X., Xu, W. X., Hong, J. P., \& Wan, S. Q. (2010). Interannual variability of soil microbial biomass and respiration in responses to topography, annual burning and $\mathrm{N}$ addition in a semiarid temperate steppe. Geoderma, 158(3-4), 259-267.

Lysenko, G. M. (2008). Pirogennye aspekty abioticheskoj reguljacii stepnyh rezervatnyh jekosistem [Pyrogenic aspects of the abiotic regulation of steppe reserve ecosystems]. Ekologija ta Noosferologija, 19(1-2), 143-147 (in Ukrainian).

Maestre, F. T, Huesca, M., Zaady, E., Bautista, S., \& Cortina, J. (2002). Infiltration, penetration resistance and microphytic crust composition in contrasted microsites within a Mediterranean semi-arid steppe. Soil Biology and Biochemistry, 34(6), 895-898.

Malinovskaja, I. M. (2012). Vlijanie pozhara na sostojanie mikrobiocenoza pochvy vos'mi- i dvadcatiletnih zalezhej [Fire influence on the state of microbiocoenosis of eight- and twenty-year deposits soil]. Visnyk Poltavskoi Derzhavnoi Ahrarnoi Akademii, 4, 20-24 (in Russian).

Maltsev, E. Y. (2015). Vlyianye raznkh shtammov roda Nostoc Vaucher ex Bomet et Flahault na rost y razvytye Pisum sativum L. [Influense of Nostoc Vaucher ex Bornet et Flahault strains on growth and development of Pisum sativum L.]. Biological Bulletin of Bogdan Chmelnitskiy Melitopol State Pedagogical University, 5(3), 148-154.

Maltsev, Y. I., Didovich, S. V., \& Maltseva, I. A. (2017). Seasonal changes in the communities of microorganisms and algae in the litters of tree plantations in the Steppe zone. Eurasian Soil Science, 50(8), 935-942.

Maltseva, I. A. (2003). Gruntovi vodorosti yak strukturnyi element Velyko-Anadolskoho kulturbioheotsenozu [Soil algae as a structural element of VelykoAnadol culture biogeocoenosis]. Gruntoznavstvo, 4(1-2), 66-72 (in Ukrainian).

Maltseva, I. A., \& Pysanets, Z. H. (2004). Gruntova alhoflora lisovykh i stepovykh fitotsenoziv na terytorii Mariupolskoi doslidnoi stantsii [Soil algae flora of forest and steppe phytocoenoses on the territory of Mariupol research station]. Visnyk Zaporizkoho Derzhavnoho Universytetu, 1, 132-135 (in Ukrainian).

Maltseva, I. A., \& Shcherbyna, V. V. (2011). Sezonna dynamika chyselnosti ta biomasy vodorostei deiakykh bioheotsenoziv stepovoi zony pivdnia Ukrainy [The seasonal dynamics of algae population and biomass of some biogeocenosis of a steppe zone in the southem Ukraine]. Visti Biosfernoho Zapovidnyka Askaniia-Nova, 13, 97-100 (in Ukrainian).

Maltseva, I. A., Maltsev, E. I., \& Solonenko, A. N. (2017). Vodorosli pochy dubrav stepnoy zonyi Ukrainyi [Algae of the soils of Ukrainian steppe zone groves]. Algologia, 27(3), 323-336 (in Russian).

Miller, R. F., Naugle, D. E., Maestas, J. D., Hagen, C. A., \& Halle, G. (2016). Special issue: targeted woodland removal to recover At-Risk Grouse and their Sagebrush-Steppe and prairie ecosystems. Rangeland Ecology and Management, 70(1), 1-8.

Mordkovich, V. G., Ljubechanskij, I. I., \& Berezina, O. G. (2007). Problema pozharov i pirogennyh sukcessij soobshhestv pochvennyh chlenistonogih v Sibiri [Forest fire problem and pyrogenic successions of the communities of soil arthopoda in Siberia]. Sibirskij Ekologicheskij Zhurnal, 14(2), 169-181 (in Russian)

Morhun, Y. M. (2010). Osoblyvosti postpirohennoi transformatsii murashnykiv u zapovidnomu stepu Askania-Nova [The peculiarities of postpyrogenic transformation of anthills in the protected steppe Askania-Nova]. Visti Biosfernoho Zapovidnyka Askaniia-Nova, 12, 97-99 (in Ukrainian).

Myers, P. E., \& Davis, J. S. (2003). Recolonization of soils by algae in a north central Florida pine forest after controlled fire and soil sterilization. Nova Hedwigia, 76(1-2), 207-219.

Pivovarova, Z. F., \& Chumacheva, N. M. (2004). Osobennosti raspredelenija pochvennyh vodoroslej na uchastkah kostrishh [The peculiarities of soil algae distribution on the areas of fireplaces]. Sibirskij Ekologicheskij Zhurnal, 4, 419-422 (in Russian)

Qi, F., Naidu, R., Bolan, N., Dong, Z., Yan, Y., Lamb, D., Bucheli, T., Choppala, G., Duan, L., \& Semple, K. (2017). Pyrogenic carbon in Australian soils. Science of the Total Environment, 586, 849-857.

Rau, B. M., Chambers, J. C., Pyke, D. A., Roundy, B. A., Schupp, E. W., Doescher, P., \& Caldwell, T. G. (2014). Soil resources influence vegetation and response to fire and fire and fire-surrogate treatments in sagebrush-steppe ecosystems. Rangeland Ecology and Management, 67(5), 506-521.

Reed-Dustin, C. M., Mata-Gonzalez, R., \& Rodhouse, T. J. (2016). Long-term fire effect on native and invasive grasses in protected area sagebrush steppe. Rangeland Ecology and Management, 69(4), 257-264.

Savadogo, P. D., Diawara, S., Dayamba, S. D., Sawadogo, L., \& Nacro, H. B. (2017). Limited long-term effects of moderate livestock grazing and prescribed early fire on soil and root processes in Sudanian savanna-woodlands, West Africa. Geoderma, 306, 18-27. 
Scheintaub, M. R., Derner, J. D., Kelly, E. F., \& Knapp, A. K. (2009). Response of the shortgrass steppe plant community to fire. Journal of Arid Environments, 73(12), 1136-1143.

Scherbina, V. V., Maltseva, I. A., \& Solonenko, A. N. (2014). Peculiarities of postpyrogene development of algae in steppe biocenoses at Askania Nova National Park. Contemporary Problems of Ecology, 7(2), 187-191.

Shcherbyna, V. V. (2014). Sezonna fluktuatsiia bioiriznomanittia alhouhrupovan tsilynnykh ta antropohenno-porushenykh bioheotsenoziv Pivdennoho stepu Ukrainy [Seasonal fluctuations of algae community biodiversiti of virgin and anthropogenic-broken biogeocenosis south steppe of Ukraine]. Jekosistemy ih Optimizacija i Ohrana, 11(30), 165-167 (in Ukrainian).

Shcherbyna, V. V. (2015). Strukturno-funktsionalni kharakterystyky alhouhrupovannia tsilynnoho typchakovo-kovylovoho stepu Biosfernoho zapovidnyka Askaniia-Nova [Structural-functional descriptions of algae associations of virgin steppe of biosphere reserve of Askaniya-Nova]. Zapovidna Sprava, 21(1), 33-39 (in Ukrainian).
Shekhovtseva, O. G., \& Maltseva, I. A. (2015). Physical, chemical, and biological properties of soils in the city of Mariupol, Ukraine. Eurasian Soil Science, 48(12), 1393-1400.

Strong, D. J., Vermeire, L. T., \& Ganguli, A. C. (2013). Fire and nitrogen effects on purple threeawn (Aristida purpurea) abundance in northern mixed-grass prairie old fields. Rangeland Ecology and Management, 66(5), 553-560.

Tooth, I. M., \& Leishman, M. R. (2013). Post-fire resprouting responses of native and exotic grasses from Cumberland Plain Woodland (Sydney, Australia) under elevated carbon dioxide. Austral Ecology, 38(1), 1-10.

Vermeire, L. T., Crowder, J. L., \& Wester, D. B. (2011). Plant community and soil environment response to summer fire in the nother great plains. Rangeland Ecology and Management, 64(1), 37-46.

Zhang, Y. M., Wang, H. L., Wang, X. Q., Yang, W. K., Zhang, D. Y. (2006). The microstructure of microbiotic crust and its influence on wind erosion for a sandy soil surface in the Gurbantunggut Desert of Northwestern China. Geoderma, 132(3-4), 441-449. 